\title{
MYTHICAL ALLEGORIES OF FEAR (A PSYCHOANALYTIC ASPECT)
}

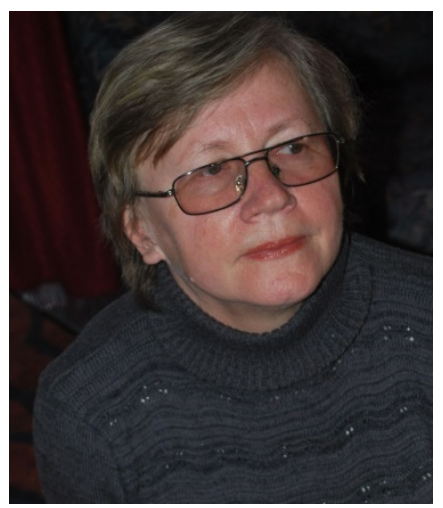

(C) Mariia Moklytsia, Doctor of Philology, Full Professor, Head of the Department of the Theory of Literature and Foreign Literature at Lesia Ukrainka East European National University, Vynnychenko Street, 30A, Lutsk, 43021, Ukraine, kaf tzl@@ukr.net

Myths of all nations filled with images of scary creatures. Historians of religion, ethnologists, experts myths explain them differently, mainly when they come together in mind that all together they certify man's fear of the gods. But this does not explain the fact that a wide variety of creepy creatures, each intricate mythology is inexhaustible and inexplicably ugly. It is proposed to take a look at the most famous monsters of Greek mythology in aspect of psychoanalytic combined with allegorical approach, since it is an allegory includes powerful resource codification mental states. Fears rights embodied in the mythical monsters and populate the world. Tree-headed Cerberus (later three-headed dragon in fairy tales) and Medusa Gorgon is the brightest in Greek mythology, allegory fear of death. Fears rights embodied in the mythical monsters and populate the world. Three-headed Cerberus (later three-headed dragon in fairy tales) and Medusa Gorgon is the brightest in Greek mythology, allegory fear of death. Fear of death is the fear of the underworld in the image of Cerberus, he exposed the relative control and can even be overcome. The horror of death which suddenly embraces man and kills her in the image of Medusa Gorgon. Allegory of the fear of death and horror of death - various images that cause different themes. Complex movements of the inner life of people have learned to understand and analyze only the new time, but even in mythical times of mankind were put into allegorical codes that are interpreted each time differently.

Key words: fear, myth, allegory, allegorical code, psychoanalysis.

Setting up a research problem. Fear is a familiar, understandable, and, at the same time, intriguing concept. Everyone knows what fear is, but his or her attempts to instantaneously reveal its nature come to a deadlock. There is an impression that the language itself resists our all-out efforts to comprehend this concept. Fear as a certain feeling and therefore, a process, is hard to define. Language contains a lot of set phrases 
to describe fear: “getting goose bumps”, “making one’s flesh creep”, “making one’s hair stand on end”, “ones heart being in one's boots”, "being petrified”, "making one's blood run wild”, “trembling like a leaf”, “making one's teeth chatter" etc. These phrases, however, categorize the changes in a human physical condition and designate the after-effects of fear per se). In other words, the afore-mentioned stereotypical word combinations came into being, apparently, after the humans had experienced fear. Fear is an extremely powerful emotion, capable of turning off intellect, thought, control along with human capacity for nominating or providing a verbal reaction. Whereas a feeling can be controlled, differentiated in accordance with its shades and phases, an emotion, as C. G. Jung claimed, is characterized by an instant change in a physiological condition of a human against his or her will, because emotions are extremely contagious: they are real carriers of a mental infection. If, for instance, you are amidst an emotionally gripped and excited crowd, you will not be able to do anything: you yourself will also be overwhelmed with this emotion (Юнг, 1995: 23).

Fear as well as aggression are fundamental human emotions that constantly push the individuals into an irrational (shadow) sphere of their psyche. When a person is struck with fear, he or she loses an ability to be conscious of oneself. This is why humans verbalize their psychological condition either prior to the state of fear (the phrases "I am, scared" or "I am frightened" express human feelings rather than the emotions proper) or after it (which was demonstrated by the above idioms). The word combination "be terrified" in Ukrainian can not be used in the Present tense. An emotion experienced at the present instant of time eludes verbal labeling.

Thus, the word "fear" in a language shuts off the specificity of the process itself, while the language offsets its inability to designate an emotion by a stable negative marking. Fear is an unpleasant emotion, whereas “anger”, another powerful emotion and a human correlate to aggression, has a range of markings: a person who is angry tends to gain strength, which surely is a positive phenomenon. Fear is ostensibly the only emotion a person would like to get rid of and remove it from his or her interior world once and for ever. It is possible, though, to experience an alternative, "light-weight" version of fear by means of a piece of art. In this case the experience of fear through art helps the individuals to block their fear in real life.

This may seem strange: fear being a defensive armour of nature serves to protect a human being in an extreme situation. Instantaneously affecting a human's physical condition, fear gets a person to escape, hide and evade death. This mechanism, however, periodically misfires, as it were, in terms of its efficiency (aggression and anger always provide for human safety). For example, a panic terror (fear of the greatest intensity) 
does not only boost the human ability to survive but also serves as an additional source of jeopardy, even as a cause of death. From the outset, that is, from the time of archaic civilizations, people began to be frightened of one of their natural functions - the emotion of fear. Joseph Campbell could have entitled his book as "The Hero with Myriads of Faces”, because its story examines not only a mythical hero who sets out to combat a monster and to defeat it but, literally, concerns any other person. In their minds people occasionally become warriors on a viburnum bridge and cut off the heads of the Dragon.

The people have been fighting against their fears since ancient times. The question arises though, why the singular form of fear is imperceptibly but steadily replaced by its plural forms (fears). This issue is worth considering. The animals obviously are devoid of fears ("fears" is used here in the plural from, unless there are cases of fixed personalization of specific hazards). The animals experience the same fear of both injury (involving pain) and death. This is what is known as primordial fear embedded in the nature of most living creatures. This is an invariably single, one and the same, emotion. Whence the plural form then? As distinct from animals, people experience a great variety of fears. Besides, those fears are hard to cognize; they are always hiding in a secret dark room with a door without a key to it (or with a key but without a permit to enter it).

Human psyche (unlike that of the animals) is divided (in the course of cultural and economic development of civilization) into two spheres: conscious and unconscious. Human beings realize their identity and, therefore, constantly modify a correlation between consciousness and unconsciousness. An individual's fight against fear constitutes an important aspect of this process. Surmounting this fear a person pushes it or squeezes it out into the cellarage of his or her psyche. As this process takes place fear is split into fragments; it becomes highly individual and conceals itself behind a diversity of masks. Fear is an emotion experienced by all people, but a type of fear each person is afflicted with varies. In an interior life of each particular individual the number of fears is infinitely large; some fears give way to others, the fears the people try to conquer are renewed; new fears are generated and there is no end of their oppressive string.

Setting up a research hypothesis. I offer a new angle to the analysis of the universally known myths. To get a better view of this phenomenon I will resort to a number of approaches borrowed from such adjacent fields as mythological criticism, psychoanalysis and theory of literary criticism, because I believe that the concept 
"myth" taken in conjunction with the concept "allegory" can provide a key to the study of a psychological content of literature.

Allegory as a literary device was known to ancient classical literature. I will mention a few names of the scholars whose research has direct implications for the issue under consideration: F.Schleiermacher, F.Schelling, E.Taylor, N. Frye, A.Losev, H-D Gadamer, R.Barthes, P. Ricoeur, Yu. Lotman, S. Averintsev. In Middle Ages allegory was a research target of hermeneutics. Allegory pervades scriptural texts. "Allegory is the prime figurative device of Holy Scripture and cannot be beyond interpretation". That is why an allegorical understanding of the Bible, according to Z. Lanovik, marks the inception of the methodology of the Humanities (Лановик, 2006: 518). Before the $18^{\text {th }}$ century allegory was often treated as a synonym of symbol. Both terms signified a figurative portrayal and its multidimensional understanding and interpretation. W.Benjamin who studied the drama of the Baroque period wrote in the 1920s that in the period between the end of the $18^{\text {th }}$ and the turn of the $19^{\text {th }}$ centuries a symbolized thinking was opposed to the original allegorical form of expression with so high a degree of alienation that separate attempts to provide a theoretical background of allegory were futile, which was another convincing proof of the depth of the antagonism (Беньямин, 2002: 165). This opposition between an allegory and a symbol continued during the $19^{\text {th }}$ century. Taking up the idea of a symbol as poetry and an allegory as didactics, the symbolists managed to elevate the symbolic image to a higher rung of the hierarchy of the models of literary expression and substantiated a non-poetic nature of allegory. Since then an express opposition between an allegory and a symbol became a commonplace in a theory of literature . S. Averintsev's Glossary is a graphic example of this approach (Аверинцев, 1999). Rationalism of an allegory is contrasted to intuitiveness of a symbol. Rationalism and the use of allegories in didactics, moral declarations and treatises caused prejudice amidst romanticists, neo-romanticists and symbolists against its artistic potential. In spite of these seemingly undeniable claims a contemporary literature (specifically, literature of modernism and post-modernism) does not keep aloof from allegories. It should be emphasized though, that modern writings of the afore-mentioned type are extensively exploiting an absolutely different aspect of an allegory, the facet overshadowed by its thousand-year rational-didactic application. In the meantime, it is a myth that demonstrates to us now an important function of an allegory: encoding elaborate psychological processes.

The plot of a mythical hero who is certain, in one way or another, to go into a combat against a monster and defeat it has always been a topic of general interest. Equal consideration deserves the characters (or beings) who oppose the main hero during a 
decisive battle. Ugly and loathsome, omnipotent and exercising power over humans, they densely pervade a mythical pantheon. The abominable creatures are often polymorphous and many-headed and, besides, display an ability to regenerate after being slayed.

Presentation of the Core Material of the Research. Cerberus is the watchdog who guards the gate of the underworld of the dead (the Subterranean Kingdom). He has three heads and a snake's tail. Heracles, however, has done the impossible: one of his daring exploits was fetching up Cerberus from the lower world onto the earth and daylight. Heracles did not slay the monster; instead he just released the monstrous creature back into the lower world. According to the authors of "The Encyclopedia of Symbols", "The legend of Heracles" exploit points us towards a path a hero should traverse to defeat the monster of the mysteries of his own soul. A triple-headed watchdog is a creature vastly opposed to God and signifies, as a matter of fact, the last fear the town was supposed to get over. As for instance, Virgil and Dante detect a three-headed monster in the bottommost depth of hell and never rise to higher spheres until they succeed in passing this obstacle through" (Бауэр, 1998: 166). Referring to Macrobius, a medieval mystical writer ("Saturnalia", $15^{\text {th }}$ century) and, in a general context, to a medieval tradition of interpreting this image, the researches argue that Cerberus' three heads symbolize time (the past, the present and the future). How can this be accounted for? Everyone knows that over the course of time a human being is physiologically unable to win a battle (i.e. defeat the monster). Moreover, time can not be personified as a monstrous creature.

Even if we disregard the results of the psychoanalytic interpretations (the underworld is a symbol of the unconsciousness), it remains evident that the subterranean world wherein the dead exist is fearsome and obscure owing to the fact that the prevailing fear of the ancients (as well as of our contemporaries) has the same name - death. Cerberus who is guarding the kingdom of the dead against the incursion and curiosity of the living is an embodiment of the fear of death. To be more accurate, an allegory of fear.

The fear of death, however, is not a mere emotion. In myths, especially in rigid plots, there are a lot of ways of overcoming the fear the essence of which is that it is multiheaded and renewable.

The fear of death eludes naming. The fears experienced and fixed by people are based on substitution; as a rule, they are metonymical when it comes to death: dangerous places, disgusting enemies, rather than death itself. 
By cutting off the monster's heads, a person cannot obliterate it. What he can do is to force the monster to retreat. The symbolic value of Cerberus' three heads varies in culture. While those are the symbols of the past, present and future, Cerberus personifies humans' fear of their own temporariness, that is, mortality.

Human mortality, however, can be signified by a variety of fashions because human fears are numerous and unconquerable.

The hero's combat against a monster makes the latter retreat to its subterranean irrational world (I can't resist the temptation of a psychoanalytic interpretation of the following poetic detail: Cerberus is fearful of coming out in the daylight; if this happens, he secrets a poisonous spit; in symbolic terms, a truly irrational phenomenon coming out the light of consciousness can often poison a psyche). The monster does not disappear; he gives up fighting, accepts defeat and, being pacified, gives the hero a free rein.

Let's restore in our memory the way Cerberus is portrayed in Dante's “The Divine Comedy”. Terrifying pictures of Dante's hell are pervaded with mythical scary creatures that do not produce an impression of being created speculatively and rationally. In contrast to numerous allegories generating their politically-motivated circumlocutory and under-the-surface meaning, the dreadful creatures of Hell (despite their fairy-tale unreality) look fairly credible and scary, indeed. This psychological verisimilitude has a single source: the author's real fears, or, to be more precise, his or her unsurmountable fears of death as an infernal punishment in hell.

As a matter of fact, a descent to Hell, to the underworld, can be equated (in terms of the present day understandings) to a transparent allegory of a journey to one's own unconsciousness, with its prime narrative pivot - the battle against fears. These fears are represented as frightful images. I believe, it is time we stopped referring to them as universal or even as those borrowed from myths: they are exceptionally individual and exist only in relation to the fear of a particular person.

This is actually an individually discovered way of encountering one's own fears directly, face to face, as it were, rather than a few socially oriented fears, expressed in terms of religion. Dante's comment on the infernal creatures is fairly indicative and frequently quoted: "That hue which cowardice brought out on me, / Beholding my Conductor backward turn, / Sooner repressed with him his new colour” (Данте, 2006: 59). 
No less indicative is the personification of human fears by the mythological Medusa, one of the monsters known as Gorgons. This is a mysterious and enigmatic character in Greek mythology. According to the account, her severed head was given to Athena, who placed it on her shield. Let's recall that Athena was Zeus's daughter (she sprang from his forehead). Medusa had two sisters. Their gaze caused death.

Disgusting creatures with a murderous gaze. What did they signify? How can we decode this laconic message? As we know, Perseus, the hero, was able to slay Medusa Gorgon. Perseus guided himself by her reflection in a smooth, mirror-like shield (thus evading her fatal gaze). As a result, Perseus decapitated Medusa as she slept.

This narrative provides the people with an allegorical formula that helps them to overcome fear before death: one cannot look in the face of death, otherwise he or she will inevitably be struck with horror of death, which may have fatal consequences. As evidenced by medicine this effect does really take place: a sudden and unexpected overmastering terror may kill a person, whereas a fear of death (if it has approached suddenly) is invariably a terror or a mortal pain, as the medieval thinkers claimed. This is the terror of death rather than the fear of death. Fear is an emotion having its origins in the times more ancient than those of the birth of civilization. The fear of death is characteristic of all animate beings. Martin Heidegger treats fear as a crucial modus of being and warns against confusing the fear of non-being with the terror of death (Хайдеггер, 2003: 286). Any conscious being is attended with a fear of death. The terror of death, though crucial for the human's relationships with death, is a condition beyond reflection.

"The fear of death felt by primitive people, - wrote Mircea Eliade, - is a fear of initiation". If there was an opportunity to conceptualize and verbalize (by means of symbols) the primitive people's anxiety, they would essentially say the following: this is the great initiation challenge, this is a penetration into a labyrinth or wilderness, which correlates with the penetration into Hell, the other world; this great fear paralyses a would-be initiate when he or she is swallowed by a monster to find him/herself in the belly of the beast; or when this initiate is cut into pieces or is digested to be born again as a new person. Let's recall all those terrible rituals related to the initiation of the young people in archaic societies; these challenging rituals, necessary in any act of initiation, still exist in some mysteries of Greek-Oriental antiquity (Еліаде, 2001: 155156). 
It is possible to conquer a fear of death by looking at its imprint, to put it differently, by finding, in one way or another, some mediation, by extracting it from one's interior world and looking upon it as something extraneous.

None of the heroes is able to overcome the terror of death. There is not a single hero who can stand the gaze of Medusa. There is, however, a way of resisting a conversion of the fear of death in to the terror of death. One of the universal ways to gain control over the fear of death is an allegorical representation of death. This image is extensively abundant in any culture.

Actually, all allegorizations of death (their numerous versions exist in all cultures) is an opportunity not only to overcome a fear of death, but also to enter into some sort of general relations with an anthropomorphous creature: to deceive, to strike a bargain, to suborn, to persuade into adjourning or into postponing a visit to a later period of time (let's recall a story about Sisyphus who successfully shunned death).

An allegorical death is not spooky (even though horrible), because it is not too intelligent, so to say. The allegorized death is imaginary, magic and comic. A scythe on her shoulders is not a frightening weapon either (a sword or an axe would have looked much more impressive. By personalizing death the people learnt to co-exist with it; they got accustomed to it, led it into a circle of beings who are, on the one hand, accessible for perception and communication and who, on the other hand, are not unduly terrifying. The fears are a different matter. The people's insurmounted fears are epitomized in monsters. Throughout the development of culture any great fear is sooner or later personified as some terrifying and scary creature. A triple-head Cerberus (a three-head dragon in fairy-tales) and Medusa Gorgons are allegories of a prime fear, the fear of death. There is an essential difference between the human fears of the two aforementioned beings: the fear of death personified as the image of Cerberus is amenable to a relative conceal and can even be conquered, whereas the fear of death represented as the image of Medusa Gorgons paralyses a person instantaneously and unexpectedly and causes death. The allegory of the fear of death and the allegory of the terror of death are distinct types of images generating different plots.

One more aspect of the myth of Medusa Gorgons deserves special consideration. In Greek mythology a winged horse, Pegasus sprang from the blood of Medusa as she was beheaded by the hero Perseus. Perseus' stay is a favorite theme of whole lot of poets. In psychoanalytic terms by doing away with the fear of death the hero discovered a source of poetic inspiration. Isn't any kind of poetic activity a struggle against fears? 
Isn't it possible to regard "sublimation", the concept of Zigmund Freud's psychoanalytic theory, as a way of overcoming fears in the process of creative (aesthetic) writing?

Conclusions. The characters of ancient myths serve as allegories, rather than symbols or archetypes within any culture. A distinguishing property of an allegorical content is its negative marker: a hideous look. An allegory is capable of personifying the acquired experience as expressive images, the latter being not only didactic but also staggering. The expressive mythic images accumulate an extremely profound psychologism and tap deep reservoirs of human experience. We have to focus our attention on this exceptional psychological value of ancient allegories in each specific case of their application. Extraordinarily subtle and intricate stirrings of human interior life (the area the people learned to explore and analyze only in modern times) were represented as the tokens of deep meaning and comprehension in as early as a mythical period of humankind.

\section{REFERENCES}

Авериниев, С. С. (1999). «Алегорія», в Софія - Логос. Словник. Київ: Дух і Літера.

Бауэр, В., Дюмоти, И. и Головин, С. (1998). Энциклопедия символов, пер. с нем. Москва: Крон-Пресс.

Беньямин, В. (2002). Происхождение немецкой барочной драмы, пер. с нем. С. Ромашко. Москва: «Аграф».

Данте, А. (2006). Божественна комедія, пер. з італ. і коментарі Є. А. Дроб'язка. Харків: Фоліо.

Еліаде, M. (2001). «Міфи, сновидіння і містерії», в Мефістофель і андрогін, пер. 3 фр. Г. Кьорян. Київ: Видавництво Соломії Павличко «Основи», сс. 117-301.

Лановик, 3. (2006). Hermeneutica Sacra. Тернопіль: ВВД ТНПУ.

Хайдеггер, М. (2003). Бытие и время, пер. с нем. В. Бибихина. Харьков: Фолио.

Юнг, К.-Г. (1995). Тэвистокские лекиии. Аналитическая психология: ее теория и практика, пер. с англ. В. Менжулина. Киев: СИНТО.

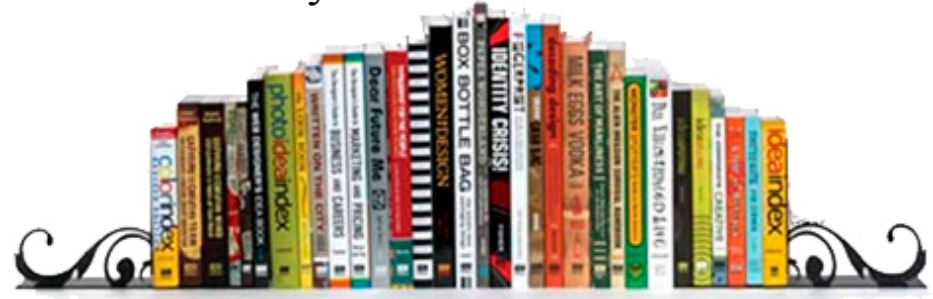

